\title{
A sustainable aspect for safeguarding a protected area: case study - Siwa Oasis
}

\author{
M. Tawfik \& M. Tolba \\ Department of Architecture, El Shorouk Academy, Egypt
}

\begin{abstract}
Protected areas are locations which receive protection because of their recognized natural, ecological and/or cultural values. Protected areas are essential for biodiversity conservation. They are the cornerstones of virtually all national and international conservation strategies. They are areas set aside to maintain functioning natural ecosystems, to act as refuges for species and to maintain ecological processes that cannot survive in most intensely managed landscapes and seascapes. Protected areas act as benchmarks against which we understand human interactions with the natural world. Today they are often the only hope we have of stopping many threatened or endangered species from becoming extinct. So the liability issue concerns the search for a protected Siwa characterized by unique biodiversity, geological formations, differentiated environments and lakes which are visited by a lot of migratory birds. It is exposing many of the risks of pollution and degradation and distortion of the urban environments. So this research aims to develop a vision for the future and the foundations of governor aspects to achieve environmental sustainability in protected Siwa, through the study of environmental sustainability aspects in the protected areas and to examine the application of these principles in Siwa in Egypt to determine the shortcomings and problems dogging this region and to place the guideline principles for solving the sustainable problem in Siwa Oasis to keep it from deteriorating.

Keywords: protected areas, sustainability, Siwa protected, urban environments.
\end{abstract}

\section{Introduction}

Siwa Oasis which is located in Matrouh governorate was declared a protected area according to a decree issued by the Prime Minister under number 1219 for 
the year 2002. (Figure 1 shows a map of Siwa oasis.) The protected area encompasses $7800 \mathrm{~km}^{2}$. It is divided into three main sections: the first is located in the east on the western border of Katara low land. Its area reaches $6000 \mathrm{~km}^{2}$ and includes Stra, Nawamisa, Aarag, Bahrain, Tabaghbagh and Great Om AlSagheer. The second section, encompassing $1700 \mathrm{~km}^{2}$, lies in the wet on the border with Libya. It includes: OmAlGhezlan, Garba, Shyatah and AlMalfa. The third section, which is the middle section, includes: Bear Wahed and part of the Great Sand Sea. Its area encompasses $100 \mathrm{~km}^{2}$. There is a biological diversity in Siwa Oasis. This is exemplified in the presence of 40 species of plants whether pastoral or medical. There are also other kinds of plants that are used in stabilizing the sand. In addition to that, there are also various kinds of trees like sent. There are about 28 kinds of mammals; some of which are threatened by extinction. Also, there are 32 kinds of lizards and 164 types of birds. There are various kinds of spineless animals and insects. This oasis also holds a historical and cultural value which enables it to be one of the most important cultural centres of the world.

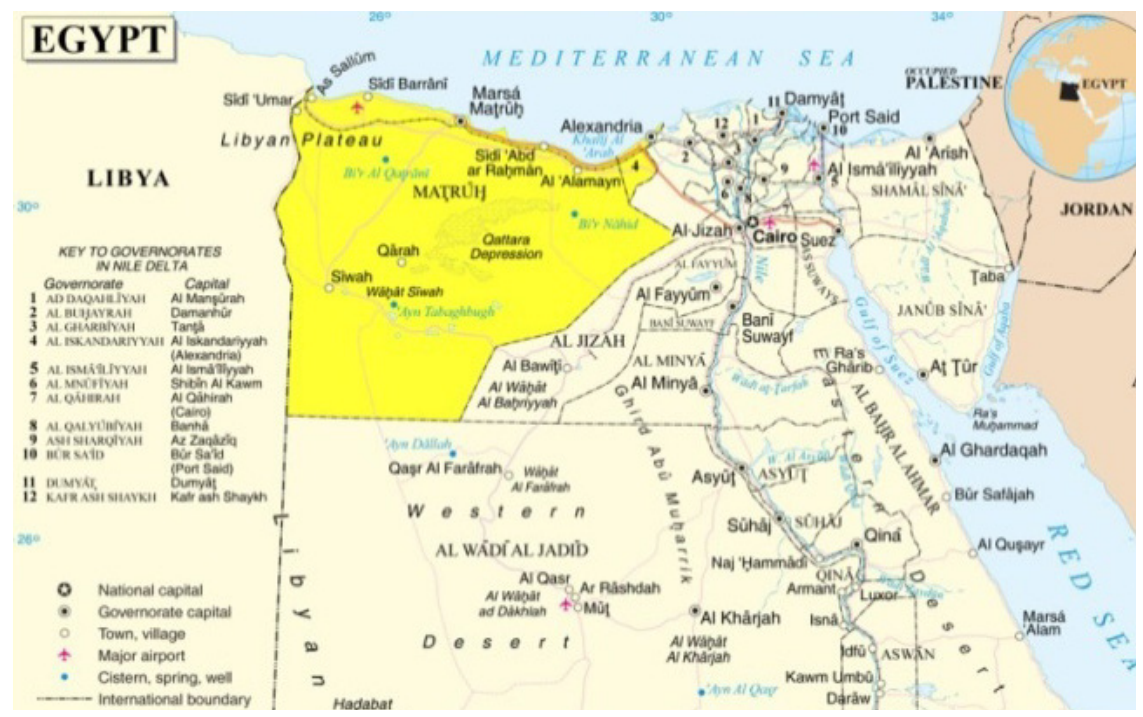

Figure 1: $\quad$ Siwa Oasis map.

The presence of the biological diversity in Siwa Oasis, as well as the different geological formations (damp soil, sand hills, and valleys) creates the perfect environment for sustainability. There are also lakes that attract different kinds of migrating birds. In addition, Siwa Oasis has the elements that enable the development of tourism as it contains ancient Egyptian and Roman monuments. In addition to medical tourism which uses sand and warm spring water for healing and recovery, the above mentioned is known as environmental tourism. In Siwa there is a whole region which presents the typical idea of the Sahara. This means that the area is dry and there is no life in it except for animals and 
plants adapted to the area formed into quick sand hills, valleys and stony hills which reflect the rare geological nature that has formed over thousands of years. Despite the rarity of rain, it can be seen that there is a number of valleys and smaller oases that have underground water. That is evident in the presence of plants that cover the earth surface in this area. In addition to that, there are water springs, lakes and wet lands which provide life for endangered animals and plants. There is diversity within the historical and cultural heritage in Siwa Oasis. This is evident in the Hill of the Dead which contains a number of mummies. It also contains Alexander the Great's coronation hall, Ammon temple and the National Heritage museum which showcases the hand made products and crafts of the locals. The main goal of this research is to study the different methods that should be followed for developing and protecting the natural, historical and cultural treasures of Siwa Oasis and converting it into a main touristic spot for the whole world to visit.

This paper consists of four parts, the 1st studying the sustainable aspect in a protected area, the 2nd studying these aspects in protected Siwa, the 3rd part determining the shortcomings and problems dogging this region and the 4th part placing guidelines for solving sustainable problems in Siwa Oasis to keep it from deteriorating.

\section{The sustainable records in protected Siwa}

\subsection{Energy}

\subsubsection{Solar energy}

Solar radiance ranges from $86 \%$ in winter to $99 \%$ in summer; which makes this region one of the top regions rich in solar radiance. Therefore, Siwa Oasis can be considered as one of the most suitable places to use solar energy. Siwa has a tropical climate as the temperature rises to the utmost during summer; especially in July as it reaches 38 degrees centigrade. The General Administration for Urban Planning has made a study that is concerned about the inclusive strategic development for Siwa Oasis 2022. This study shows that using solar energy in Egypt can save about 3.5 billion $\mathrm{kw} / \mathrm{h}$ and that is only domestically. It can also save 2.2 million tons of fuel. The study has made recommendations for using solar and wind energy in several fields such as: heating water, drying crops, irrigation, milk production, domestic birds' ranches, livestock, land recovery for planting, etc., in the study at hand [1]. We do not recommend using such energy as it negatively affects rare birds which live in the area.

\subsubsection{Wind}

The oasis also has fast, low wind which ranges in velocity between 2.5 knots during November and 4.8 knots during March within an annual average of 3.8 knots. That is why the velocity of the wind cannot help in electricity generation [1]. 


\subsubsection{Warm water springs}

They can be considered as a source of energy. In Japan, electricity is generated by using the difference between the temperature on the surface of the sea and that in the depth under water. This process is called conversion of sea energy (OTEC). This means saving electricity and pure water. The springs can also be used in getting hydrogen which is used in fuel cells. The energy can be gathered by recovering hot water and steam from underground. The steam can be used in moving electricity generators. In this way, the energy coming from underground is now a source of electricity. Japan has 17 stations of that kind of electricity generation. The biggest is Hatshobara station. The station's capacity is $110,000 \mathrm{kw} / \mathrm{h}$ which can provide 37,000 houses with electricity (an average house uses $3 \mathrm{kw} / \mathrm{h}$ ). The positive aspect about such stations, in comparison to gas stations, is that they generate the same amount of electricity and emit only $5 \%$ of $\mathrm{CO}_{2}$ of that emitted from gas stations. This can be applied to Siwa Oasis as there are various warm water springs which do not need costs for recovering from them [2].

\subsection{Material}

The kerchief material is one of the materials that are found in abundance in Siwa Oasis. This material is formed as a result of the evaporation of water in mineral lakes. The salts that are left behind after evaporation mix with the soil forming clay. When this clay dries the salts mixed with dirt get solidified which means that it becomes a natural solid material. This material can be used in construction. The residents of Old Shaly used this material to build houses (as shown in Figure 2). It is considered one of the strongest construction materials the world has ever known. The proof for this is the existence of Shaly up till now with all its monuments, squares and walls. The oasis is also rich in palm trees and olive trees which are considered major sources of wood.
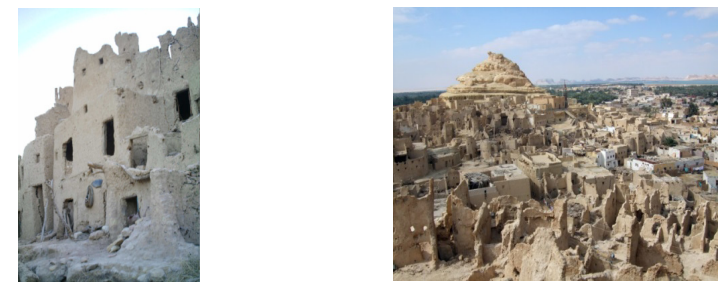

Figure 2: $\quad$ Ruins of the city of Shaly in which kerchief material was used in construction.

\subsection{Water}

Underground water is found in abundance in Siwa Oasis; it is considered the only source of water whether for drinking or irrigation. In order to put that water into use; wells have to be dug at great depths which may reach $800 \mathrm{~m}$ or more. Underground water is found in different parts of the oasis. It appears in the form 
of water springs. In Siwa there are 220 water springs. The average flow of each of them ranges from $700 \mathrm{~m}^{3}$ to $13,000 \mathrm{~m}^{3}$. Salinity ranges from 1600 to 8000 unit per million. In Siwa, shallow wells are also found; they reach 1200 wells and their depths range from $50 \mathrm{~m}$ to $22 \mathrm{~m}$. Salinity ranges from 500 to 7000 unit/million [1].

\section{Studying the sustainable aspect in Siwa Oasis}

In this part of the research, a study of five guiding principles for sustainable urban design in Siwa Oasis is conducted to identify the problems to be considered when preparing a sustainable urban design and urban harmony that responds to the surrounding environment and local community, and suits the people, their cultural, social, psychological and economic background.

\subsection{Energy}

Diesel generators feed Siwa Oasis and neighboring villages with electricity. These generators are not connected to the unified network of the rest of the country. The number of transformers in the oasis reaches 42 ; the transformers work at $50 \%$ capacity.

There are no other electricity sources in Siwa. The Egyptian Electricity Institution is planning to provide two generator stations to produce energy.

Mineral water springs are found all over the oasis. The most famous is Kighar well in which the water temperature reaches $67^{\circ} \mathrm{C}$ and can be used as a source of clean energy [1].

\subsection{Materials}

The construction style in Siwa is characterized by using local materials like kerchief, palm branches and wood from olive trees. Kerchief, used for building walls, gets broken into flat pieces that range from $30 \mathrm{~cm}$ to $50 \mathrm{~cm}$ in length and $15 \mathrm{~cm}$ to $25 \mathrm{~cm}$ in width and a depth of $10 \mathrm{~cm}$ to $15 \mathrm{~cm}$. Those pieces are put horizontally together by using a paint derived from the same material, i.e., kerchief; which is used for painting the interior and exterior of the house. The walls are built over stages; each stage is about 1 meter long. It is left to dry for 10 days before starting the next Medamick (stage). Palm branches are used to connect the walls to each other. The palm branches are also used in building the ceiling and the frames for doors and windows. Palm tree fiber is used for filling the empty spaces between the palm branches that form the ceiling. Doors and windows are made of wood from olive trees. Figure 3 illustrates the different forms and styles of houses in Siwa.

The percentage of houses built of concrete does not exceed $6 \%$ of the total houses in the city and $3 \%$ in the village. The buildings made of holding walls and those made of clay are equal and they are about $47 \%$ of the total residential buildings. In Aghormy village, buildings made of clay exceed those made of holding walls. The ratio between them is $55 \%$ to $41.7 \%$ of the total residential buildings. 

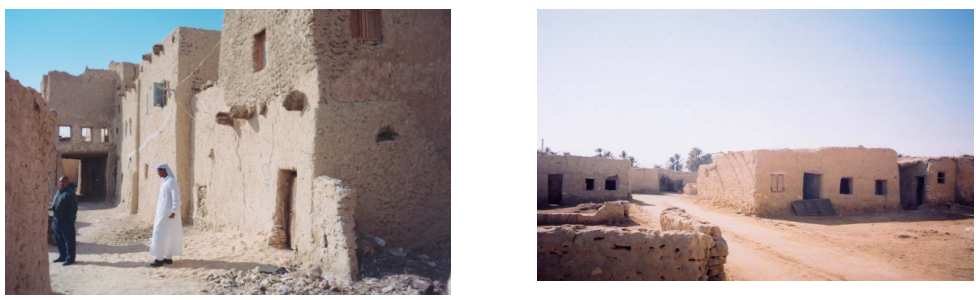

Figure 3: $\quad$ Types of houses and residential units in Siwa.

The above mentioned style of construction has led to the uniqueness of construction on old Siwa. But, the appearance of many problems has led the Siwan community to abandon the old style of building over the last thirty years. Those problems can be summarized up as follows: the weakness of kerchief in resistance to humidity. The increase in sewage water and the intense rain that took place in 1928 and 1985. The problem of white ants which was the cause of the collapse of several buildings. All these problems lead the residents to abandon the older regions in Siwa like Shaly and AlGharabeen. The seclusion of the oasis came to an end when the government decided to build some governmental buildings at the end of the 1970. It also supported the connection between Siwa and Matrouh in 1974. Moreover, television broadcast reached Siwa in 1985. The Siwans started to look forward to change. This was reflected in their use of new construction styles, especially on the North West coast and use of new materials like stone blocks, limestone and concrete [1].

The new developments in building styles lead to the distortion of the original unique building style in Siwa. Figure 4 shows how new materials have been used for interior and exterior of buildings which are strange to the Siwan environment, the buildings are decorated in bright colors, the openings of windows and doors widened and awnings disappeared from the façade

The problem of distortion of the original Siwan, urban style - especially with the increased interest in tourism in the last 10 years - led the governorate to prevent issuing any construction licenses except for buildings that will use local materials and kerchief for the exterior. This caused a big problem for the locals who started constructing random buildings. It also, led to the increase in buildings cost because of the weakness of the kerchief material.
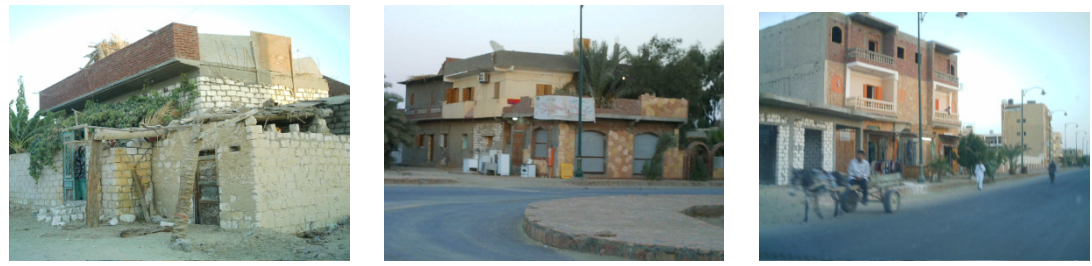

Figure 4: Use of new types of finishes and new materials in construction led to a distortion of the character of the oasis. 


\subsection{Water}

\subsubsection{Water consumption}

Statistics and field visits show that water consumption ranges between 40 to 50 liters/person/day in the countryside and rises to 60 to 80 liters/person/day in cities like Siwa city. The production of wells is sufficient to cover the places they service till the year 2022 [1].

Water infrastructure: There is a main network of water pipes in Siwa which pass through some of its streets. The diameter of the pipes ranges from 4 inches $(100 \mathrm{~mm})$ to 8 inches $(200 \mathrm{~mm})$. These pipes are made of asbestos and are in a frail condition. They should be substituted by a new network. The pipes are supplied with water from AlDakrour well through an 8 -inch wide main line. The well supplies around $10.000 \mathrm{~m}^{3} /$ day; which is sufficient for the current and future use of the city.

There is also a high water tank located to the south of the city with a capacity of $150 \mathrm{~m}^{3}$. Currently, there is a whole project under construction to supply Siwa city with water. This project includes a new network for water supply through AlDakrour well as mentioned previously. Also, there will be earth water reservoirs to collect water from wells and a pumping station to pump water from the reservoirs to the city network [1].

\subsection{Sewage}

There are no sewage projects whether in the city or the villages. Sewage is disposed of through purifying reservoirs or other methods which allow the water to seep underground.

Through field visits, it was evident that underground water has increased in Siwa city from 0.25 to $0.50 \mathrm{~m}$. This is due to the streaming of underground water from natural springs and deep and shallow wells. Also, due to the seeping of sewage water which leads to the formation of swamps. This affects the environment and public health; and the pollution of underground water.

\subsection{Waste disposal}

The technology used for the disposal of solid waste in Egypt is backward to some extent, and there is a small percentage of cities that get rid of the waste in ways that support a healthy and free from harassment existence, where the quantity used as food for animals or for the manufacture of municipal fertilizers represent a relatively small part of this waste. The majority of waste cast into the open ground dumps do not meet health requirements. These waste materials are complex and heterogeneous, and have different components for different standards of living. The rate of waste according to international standards in countries which have similar circumstances to Egypt is $1.5 \mathrm{~m}^{3} /$ per person per year, ranging in density from 0.2 to 0.4 tons $/ \mathrm{m}^{2}$ by the standard of living, and the evidence suggests that this amount will multiply after ten years not only as a result of the steady increase in population but also because of an increase in the amount of waste per person. 
It was clear from the technical data that the current energy garbage resulting from the cities and villages of the oasis, estimated at about 8tons/day, are disposed of in a landfill and are being burned. Exposed to the rest of the quantity and as the value of $1.5 \mathrm{~m}^{3} /$ capita/year, the medium value can estimate the expected amount of garbage from the oasis in 2020 to be about $37500 \mathrm{~m}^{3} /$ year.

\subsection{Transportation}

Siwa Oasis connects several local roads together. Some of those roads connect Siwa with other places and some of them connect Siwa with the surrounding local communities. The roads vary according to their length, width, pavement and traffic. Paved roads are limited locally; they connect Siwa city with some villages like Aghormy or Al Dakrour Mountain. Magles Al Madeenah Street is considered the main entrance for those coming from Matrouh. It is a paved road, about $15 \mathrm{~m}$ wide; then, there is Al Souk Street and after it comes Al-Sadat Street in order to reach the south and Mubarak city. All these streets are paved and their average width is $15 \mathrm{~m}$. There are also a number of unpaved roads with a width that ranges between 10 to $15 \mathrm{~m}$; like, Olympic Village Street, Algoma Street and Side Soliman Street. The rest of the streets in the city are unpaved and their width ranges from 4 to $8 \mathrm{~m}$.

\subsubsection{Means of transportation that are used in the oasis}

- Public transportation: such as buses and micro buses which drive people to and from Matrouh and Alexandria only.

- Private transportation: private cars are rarely used. The rate of ownership of cars and vehicles in Matrouh, over the last 10 years is very low in spite of the $8 \%$ annual increase. The ratio of vehicles to humans is 5.5 vehicles to 1000 person. The ratio of car ownership to humans is 5 cars to 1000 person.

- Stagecoaches: they are used inside the city for transporting people and goods (as shown in Figure 5).

- Bicycles: used by people for transportation inside the oasis (as shown in Figure 6).

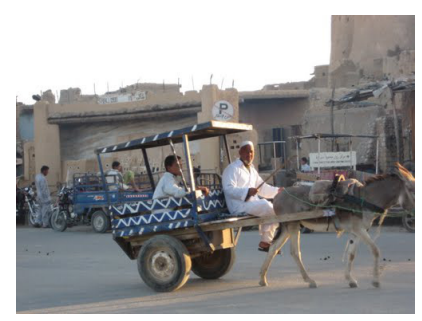

Figure 5: The use of stagecoaches.

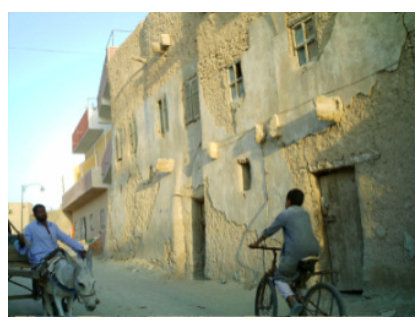

Figure 6: The use of bicycles. 


\section{The major problems facing sustainability aspects in Siwa}

\subsection{Energy}

Siwa Oasis and the neighboring regions are supplied with electricity through diesel generators which are not connected to the main, unified network of the rest of the country. There are no transforming stations that the oasis can depend on for energy generation. There are no means for electricity supply.

\subsection{Material}

The development in construction style and the materials used lead to the distortion of the original, unique building style of Siwa.

Distortion of construction style leads the governorate to prevent issuing any construction licenses; unless the materials used are natural, local materials. This has caused a problem to the residents as maintenance is costly. The result is the presence of random regions.

\subsection{Water}

- Underground water is abundant in Siwa and is considered the only source of clean water. It is sufficient till 2022 and there are no problems in water sources in Siwa Oasis.

- There are no sewage projects in the oasis. Sewage is disposed of through purifying reservoirs or other methods, some of the sewage seeps through the ground.

- The spread of sewage groves has led to clogging the pores of the soil that has led to the presence of swamps which negatively affects the environment and public health and may cause pollution of groundwater sources

\subsection{Waste disposal}

The technology used in waste disposal is outdated. The amount that is used as food for animals or used as fertilizers is very small. The greater amount is thrown into landfills which are unsanitary.

\subsection{Transportation}

Transportation problems can be summarized as follows:

- No hierarchy for road network.

- Most of the roads are unpaved.

- The city entrances need new pavements.

- Trucks cause traffic jams and are unsafe for pedestrians. 


\section{Guidelines for solving the sustainability problems in Siwa Oasis}

In this part of the research we will develop guideline principles for solving sustainability issues which can assist when planning a comprehensive strategy for the development of Siwa Oasis.

\subsection{Guidelines for solving the sustainability problems of energy resources and practices}

- In designing the site and its buildings; allow for change. During the lifetime of the project, it will probably see at least three or four different sources of energy.

- Analyze demand and supply simultaneously. Reducing the energy requirements can have environmental, economic and other benefits [4].

- Hot springs in Siwa Oasis hold the promise of providing a pollution-free source of heat and electricity. They will be an essential part of the future hydrogen economy.

- Waste is an important potential source of energy that should not be neglected. How it is treated will have a number of impacts, including those on land use and health.

\subsection{Guidelines for solving the problems of sustainable material resources and practices}

- The use of clay in the field of construction and improvement of this material for use in outside finishing in order to solve the problem of the character of buildings. The most important factor being to strengthen clay material for building materials to avoid cracking and to increase the cohesion and strength using material such as straw, natural or industrial fibers, or cement.

- Undertake research and studies to find alternative materials or develop Kerchief material.

- Evaluate options for off-site construction to reduce site wastage through damage, and to improve health and safety through controlled operations.

- The greatest inefficiencies are introduced during design and construction. Design with consideration for deconstruction, in order to reduce the quantity of waste sent to landfill, of raw materials extracted, and minimize the need to recycle.

- Design out the need for hazardous materials; consider the health and safety implications of materials in production and in use.

\subsection{Guidelines for solving the problems of sustainable water principles: resources and using waste as a resource [4]}

- Incorporated water recycling at the outset of a project. If it is not incorporated, allow for its incorporation (in terms of space for storage and pipes, dual water supplies, etc.) and consider bath water recycling. 
- Minimize demand in order to minimize waste.

- Use waste as a material resource or an energy resource.

- Minimize water use in transporting and treating human waste.

\subsection{Guidelines for sustainable transportation}

- Creating and maintaining an attractive public realm. Improved street maintenance and a more coordinated approach to street design.

- Improving the image of public transport, through investment in wellpositioned and designed stops, accessible stations and better services.

\section{References}

[1] General Organization for Physical Planning, Planning Center of Alexandria Reign, "Comprehensive Development Strategy of the Siwa Oasis", Egypt, 2006.

[2] Japan national tourism and organization; Japan the official guide http://www.jnto.go.jp Japan.

[3] El Demery, A., "Siwa between the present and the past" Hassan Yasuo, Alexandria, 2005.

[4] Ritchie, A., Thomas, R., "Sustainable urban design: an environmental approach", Taylor \& Francis, London and New York, 2006. 